\title{
THE SEASONAL CYCLE OF INSECT ABUNDANCE IN PUERTO RICAN CANE FIELDS
}

By

George N. Wolcott, Entomologist,

and

Luis F. Martorell, Associate Entomologist, Agricultural Experinemt Station of the University of Puerto Rico

Even the most single-minded entomologists find difficulty in so exclusively concentrating on a single insect as to avoid noticing other insects present in the same enviroment. The writers proved to be no exception, in their five years observations on the egg-clusters of Diatraea saccharatis $F$., for they inevitably did notice other insects present in the fields of young cane which were being examined. To be sure, the record cards had no particular space reserved for notes on other insects, but they were large enough so that plenty of space could be found, on the back, if not on the front, for writing down all sorts of notes, some with no entomological bearing. Many a card bears speedometer reading of actual miles driven, or a note on whether the field had been previously examined, or a rough field map of its exact position, or sometimes such a record as "Dry as Hell", or "Game called on account of rain."

Of those with the most direct bearing on the project are the rare records of finding an adult Diatraea moth in the field. At first also, the surprise of finding adult Trichogramma on egg-clusters resulted in a record of each such instance, but soon this ceased to be surprising, and such notes no longer appear, altho instances of finding the minute parasites in the immensity of a cane field were as common as before. It is believed, however, that all instances of finding the much less common Prophanurus alecto Crawford, in the field on egg-clusters, or emerging from collected egg-clusters, were recorded. Naturally, also, every instance of finding the little black ant, Monomorium carbonarium ebeninum Forel, eating eggclusters was incorporated in our field notes, for this was an entirely new aspect of its presence in cane fields (Wolcott \& Martorell 193\%), which actually resulted in the destruetion of a sixth of all Diatraea egg-clusters. All such notes have been includerl in our report on the main 
project; the purpose of the present paper is to summarize all the other entomological notes, which as here consolidated, form the entomological aspect of an ecological survey of fields of young cane in Puerto Rico.

No originality is claimed for the idea of such a survey, for soon after the initiation of the Sugar Cane Producers' Experiment Station at Rio Piedras, Mr. D. L. Van Dine (1913) issued an annotated list of the insects of sugar-cane in Puerto Rico. The senior writer (Wolcott 1921) made a survey from December 1920 to July 1921 of the insects which might be implicated in the transmission of mosaic disease of sugar-cane. The observations here reported, cover a longer period (five years) than any of the others, and give the present status of the insects concerned.

\section{May Beetles}

How different is the present status of some of these insects may be judged from the fact that the founding of the Sugar Producers' Station was primarily due to the need for finding some practical method of controlling white grubs in cane fields. The story of the introduction of the giant Surinam toad, Bufo marinus L., (Fig. 1 \& 2) has already been

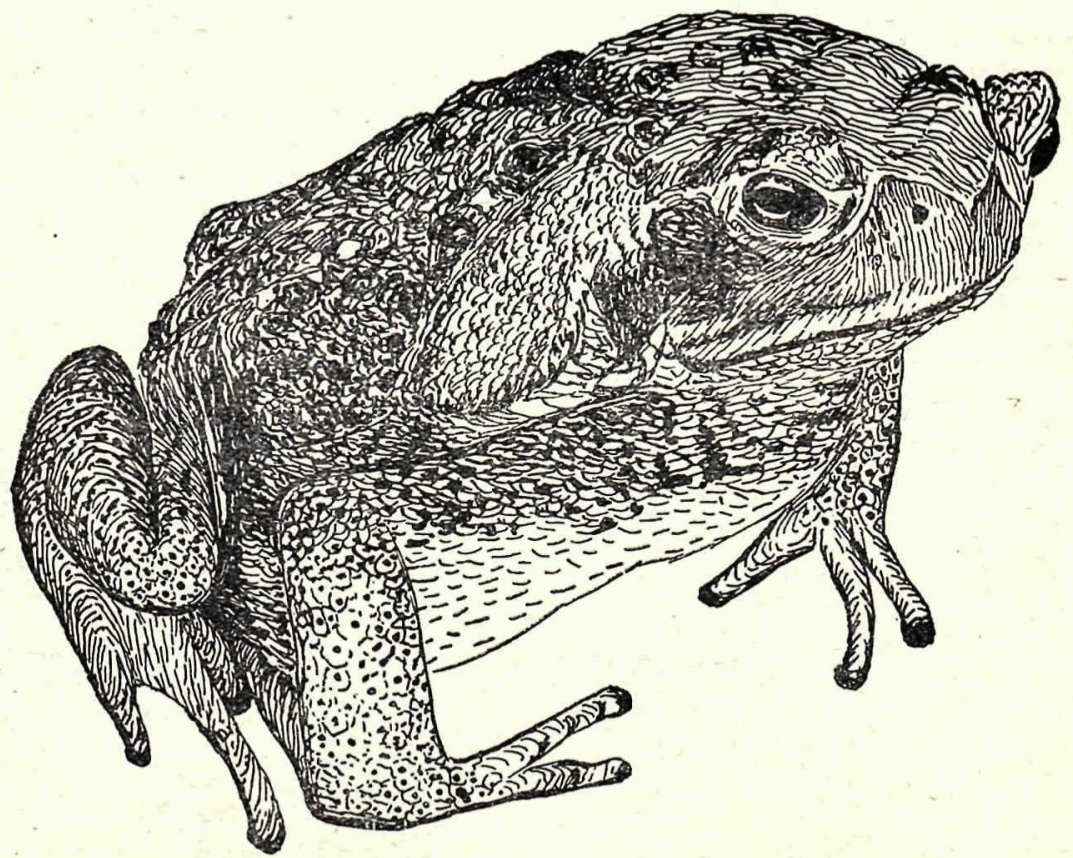

Fig. 1. The Giant Surinam Toad, Bufo marinus L., adult female, natural siz 3. (Original, drawn by G. N. Wolcott). 


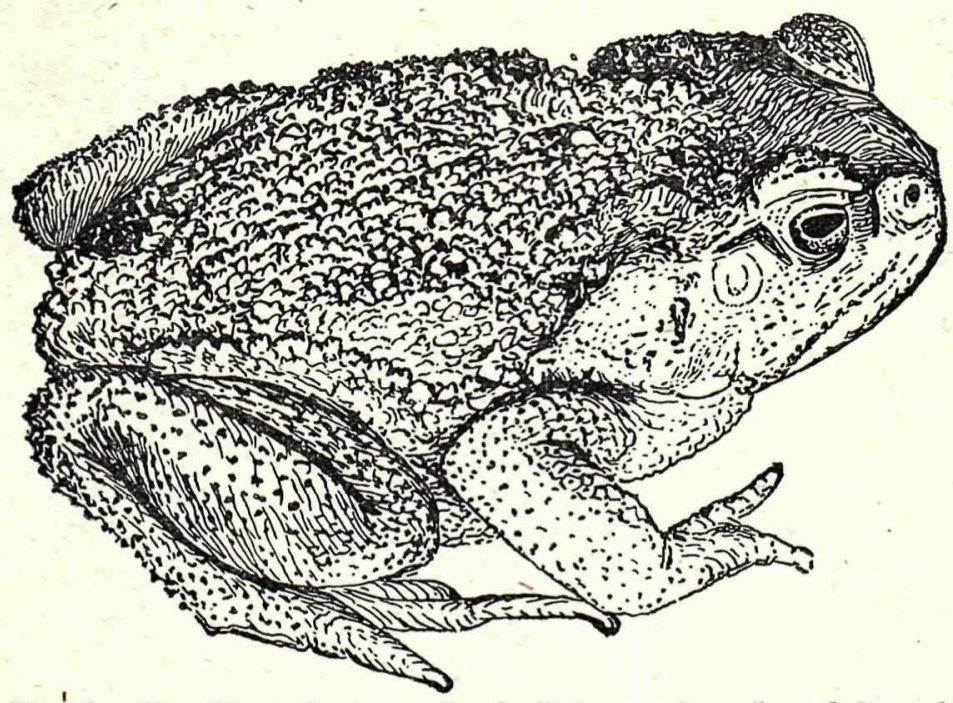

Fig.' 2. The Giant Surinam Toad, Bufo marinus L., adult male, natural size. (Original, drawn by G. N. Wollcott).

told several times (Leonard 1933, Wolcott 1935), but to one who remembers the conditions previous to its becoming abundant and omnipresent in Puerto Rico, the change caused by it in the status of white grubs seems almost incredible. Bufo was no respecter of the specific identity of May beetles, and ate the species endemic and peculiar to Puerto Rico(Fig. 3) as readily as any of those of continental South America, or those of any country into which it has since been-successfully introduced. Its environmental requirements coincide with those of the most destructive species of Puerto Rican May beetles, and when these are not available for food, eats other large insects, or millipedes, or, failing any of these, uncomplainingly retreating into shallow sheltering caves beneath clods of earth, quietly fasts until May beetles are again available. For a few years after the toads had become most abundant, they were so completely successful in the control of white grubs (Fig. 4) that an insufficient supply of food was available to maintain them in such great numbers. A more stable equilibrium has by now been established, so that while an abundance of toads promptly appears whenever an exceptional food supply develops, few are to be noted where there is little for them to eat. Localized outbreaks of May beetles still occur, and in our notes are thirteen records of cane shoots being half defoliated during April and May, one record at Arecibo in June and another at Humacao in August. In every case, pellets of toad excrement showed how 


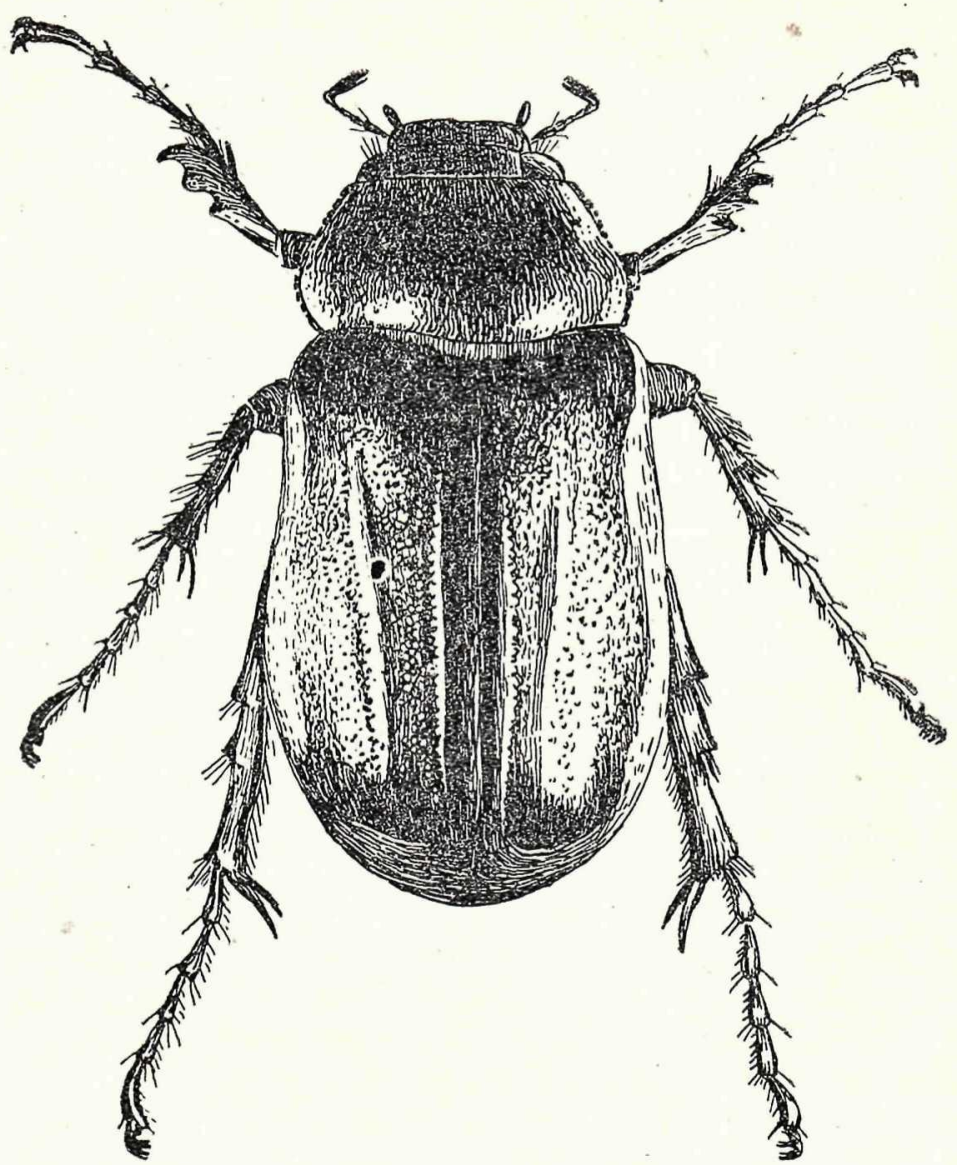

Fig. 3. The common Puerto Rican May Beetle, Cnemarachis (Lachnosterna or Phyllophaga) portoricensis Smyth, three times natural size. (Original, drawn by G. $N$. Wolcott).

temporary in character were such outbreaks, as the toads of the region had promptly mobilized where food was abundant.

\section{SOUThern Grass WorM.}

The black "hard-back" Lamellicorn beetles, the large leaf-eating" Otiorhynchid weevils or "vaquitas", and millipedes are the other largest fractions of the food eaten by toads, for their size, slowness of movement, and habits render them the most easily captured, and their abundance makes them most available. Bufo neves misses a chance, however, to feed on any- 


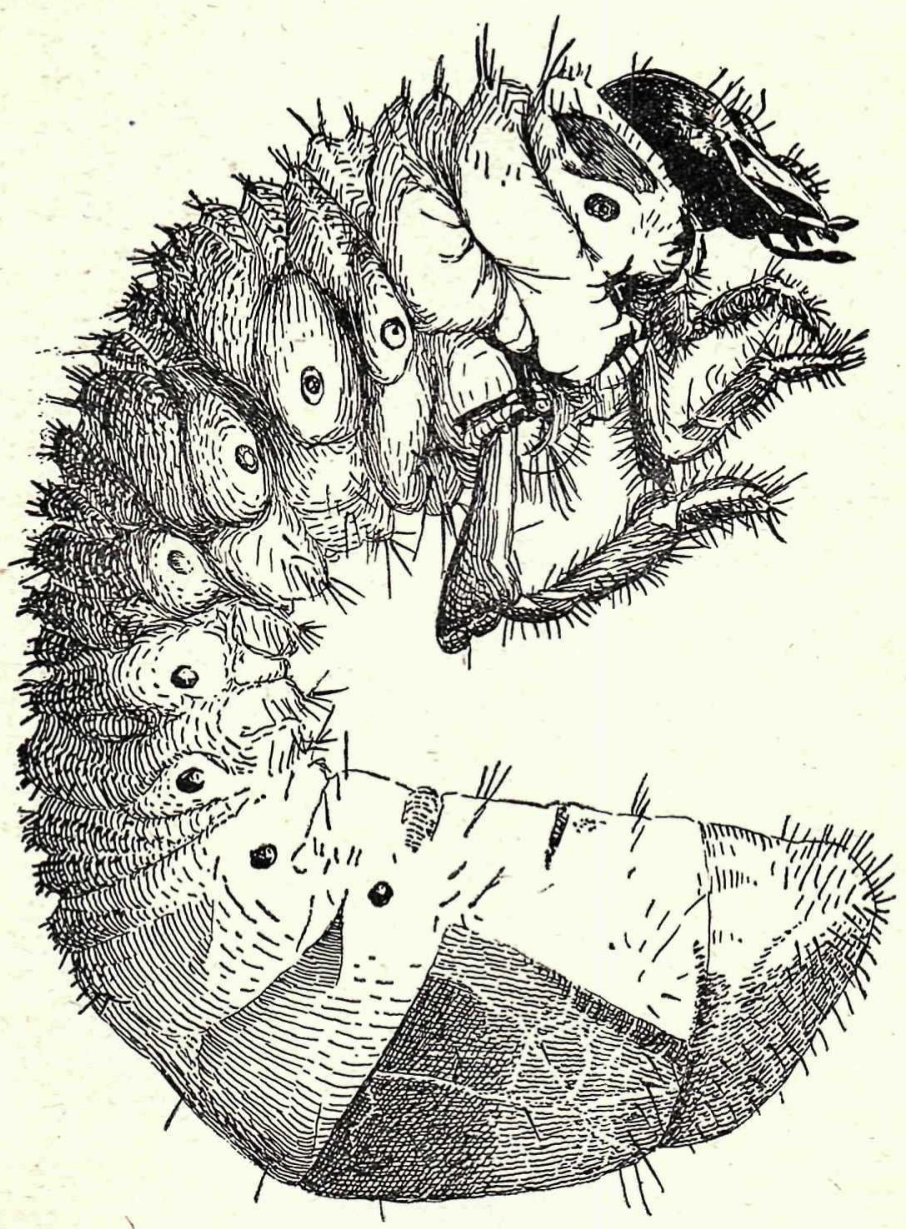

Fig. 4. The common Puerto Rican White Grub. Cnemarachis (Lachnosterna or Phyllophaga) portoricensis $\mathrm{Sm}$, th, five times natural size. (Original, drawn by G. N. Wolcott).

thing of reasonable size, and altho caterpillars consist mostly of undigested chips of leaves not yet transformed from vegetation into insect, even they are not despised by the toads. Outbreaks of the southern grass worm, Laphygma frugiperda S. \& A., (Fig. 5) are no longer as severe as before Bufo was introduced, and toad excrement in a field where these caterpillars are abundant consists largely of telescoped caterpillar skins and the skulls of Laphygma still readily identified by the characteristic inverted Y. All 


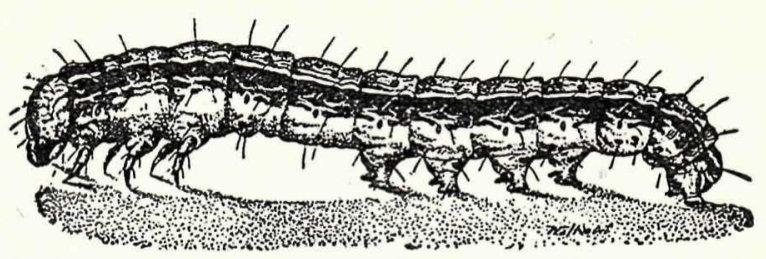

Fig. 5. Larva of Laphygma frugiperda S. \& A., twice natural size. (Drawn by W. R Walton).

the other parasites of Laphygma noted by Joiles (1913) are also present: the Tachinid flies hovering about, the cocoons of Apanteles marginiventris Cresson on cane leaves, the adults of Chelonus insularis Cresson looking for egg-masses to parasitize, and very rarely a mummied caterpillar with cocoons of Euplectrus beneath its shrivelled remains. Of course Bufo eats the parasitized caterpillars as readily as those which have escaped their numerous enemies, and might readily eat the parasites also, if they were not too quick-moving to be caught. In the complex of competitive forces its presence is thus not exclusively beneficial to the interests of the cane grower, but the total effect seems to be that rarely does an outbreak last for more than a single generation of caterpillars. Our notes concerning fields which were observed a number of times are of complete recovery

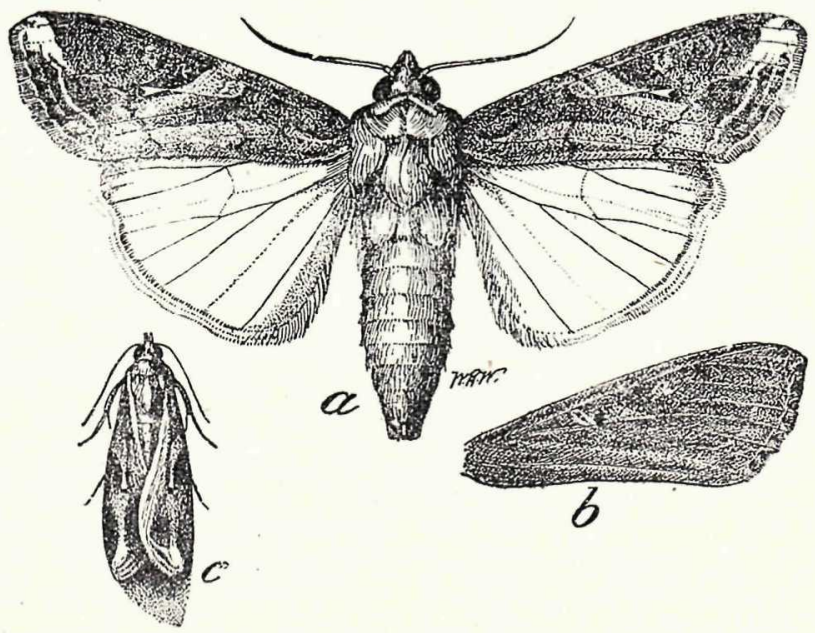

Fig. 6. Laphygma frugiperda $\mathrm{S}$. \& A., adult with folded wings $(c)$ is natural size. (Drawn by W. R. Walton) 
by the fillowing observation, usually a month later, accompanied by an abundance of parasites with nothing to attack, and of pellets of toad excrement mostly composed of caterpillar skins.

As a pest of sugar-cane, Laphygma frugiperda (Fig. 6), is usually considered of only minor importance, because outbreaks are so promptly outgrown and leave no trace in the mature crop. Its actual status is more serious, for the cane crop has only so many months in which to reach maturity, and if one or more months is sacrificed at the beginning to make up for what Laphygma caterpillars have eaten, the injury in just that fraction of the growth period. Indeed, our search for the egg-clusters of Diatraea saccharalis was so often rewarded with much larger and more easily seen egg-clusters of Laphygma (Fig. 7), as to suggest that the hand-

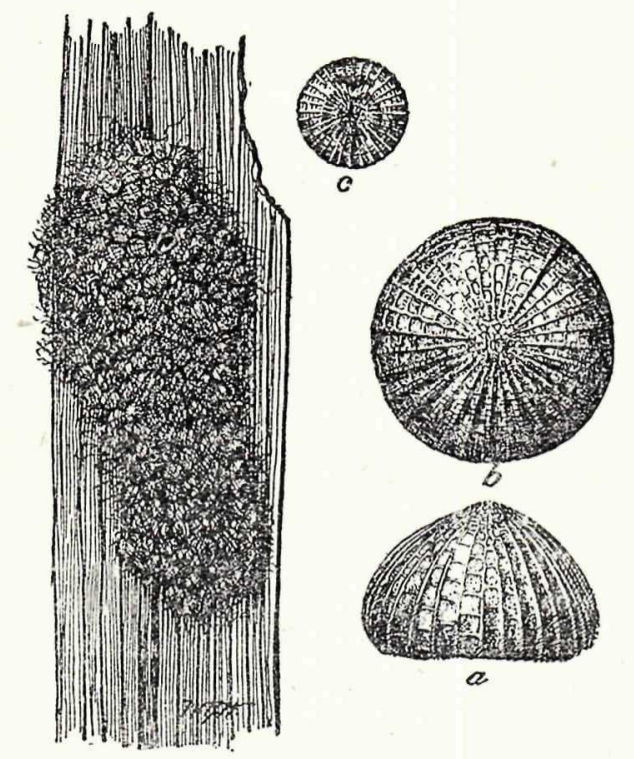

Fig. 7. Eggs of Laphygma frugiperda S. \& A. Egg mass at left about twice natural size: (a) highly magnified egg, side view; (b) same from above; (c) egg ready to hatch, larva showing thru the shell. (Drawn by W. R. Walton).

collection of Laphygma egg-clusters would be an inexpensive method of protecting young gran cultura cane from its attack. During five years observations in June, not a single Laphygma egg-cluster was noted, but in July and August records begin to appear and of first injury by cater- 
pillars, going up rapidly in number and intensity in September and reaching a peak of fifteen records of severe injury in October. We have few records for November, but again a considerable increase in December, and scattered records for the remainder of the year. Since it is thus possible to predict with reasonable assurance that injury is most likely to occur in September and October, hand-collection of egg-clusters. in August and September might prevent outbreaks. Indeed, at least a preliminary inspection of all young plant cane at any time of year would appear to be justified.

Mocis REPANDA

The looper caterpillar, or "argrimensor", Hocis repunda $F$., is quite as destructive as Laphygma, but rarely so abundant (Jones \& Wolcott 1922). It follows the same seasonal pattern of abundance: our records of injury being for October, November and December; pupae and old injury in January, one record of small caterpillars in February at Manati and another in July at La Vega, Arecibo. In some years, it may not be observed at all, our first record being in 1939, but at times in the past it has been noted to sweep a field of young plant so clean that nothing remained but the naked central shoots.

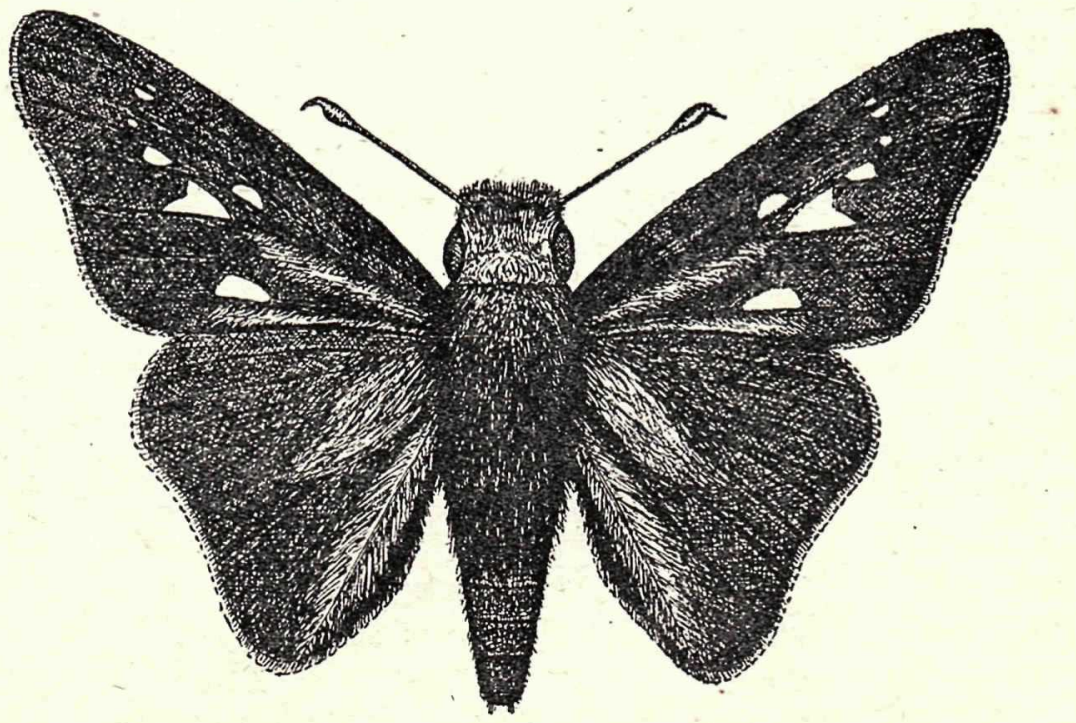

Fig. 8. Panoquina nero F. Twice natural size. (Drawn by Thos. H. Jones). 


\section{HESPERIID BUTTERFLIES}

The little brown skipper butterflies (Fig. 8), looking like minute fighter or pursuit planes with their stubby bodies and short wings, occur in cane fields because their caterpillars (Fig. 9) feed on cane leaves, or

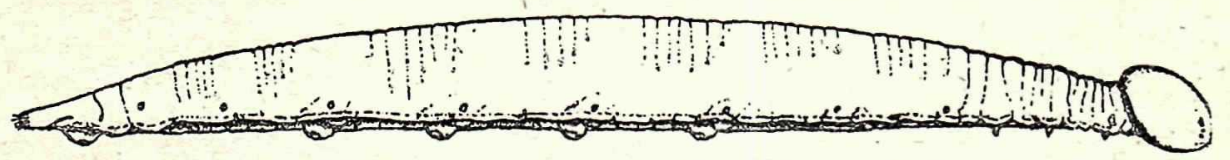

Fig. 9. Larva of Panoquina nero L. Twice natural size. (Drawn by Thos. H. Jones):

the blades of other coarse grasses. Economically they appear to be of very minor importance, but this is only because their specific egg-parasite, identified by Mr. A. B Gahan as an undescribed species of Ooencyrtus, is so abundant. From October to February, when eggs are most numerous, two-thirds or more of all eggs collected are black with parasitism, and all of the smaller number of eggs during the summer are parasitized. We noted not a single caterpillar from April to September, but in October they were quite abundant at many points in eastern Puerto Rico, and in most winter months were noted repeatedly at Rio Grande. The Vespid wasp, Polistes crinitus Felton, was twice seen eating caterpillars. The eggs and smaller caterpillars of the more common Panoquina (Prenes) nero nero $\mathrm{F}$. are practically indistinguishable from those of Panoquina nyctelius coscina Herrich-Schaffer (=Prenes ares Felder), and we made no effort to do so. The large Herperiid, Perichares coridon coridon F., is so conspicuous because of its size and hairyness that we could be sure of every record. Caterpillars or pupae were found only from September to April, and only on the north coast: Coloso to Mameyes. One fully grown caterpillar, possibly attempting to pupate, was found being eaten by crazy ants, Prenolepis longicornis Latreille.

\section{A LeAF-Tyer}

Ruining the appearance of young cane fields, but at present of no economic importance in Puerto Rico because of its scarcity, is a leaf-tyer, Marasmia trapezalis Guenée, the caterpillas of which feed on the tips of the leaves of young cane. The first record of this insect in Puerto Rico was at Barrio Camaceyes, Isabela, in July 19:31, a single caterpillar only in a large cane field, which was reared to adult and determined by the late Dr. William Schaus as $M$. similis von-Hedemann. The type of $M$. similis is from St. Croix, but in economic literature it has not been re- 
corded from there as a pest of sugar-cane. Mr. Carl Heinrich states that the specimen identified by Dr. Schaus agrees in all details with typical trapezalis, previously recorded as a pest of sugar-cane from Hispaniola and Peru (Wolcott 1929). Our records in Puerto Rico would appear to indicate its recent arrival from Hispaniola; very abundant in Barrio Aguacate, Isabela in October 1936, as well as in another field near Camuy; also very abundant in two fields at Guanica in November 1939, and in a field at Yauco in December 1936, and one at Sabana Grande in the same months in 193\%. The only other record of its presence is in July $193 \%$ at Guayanilla. All of these localities are on or near the west coast of Puerto Rico, closest to Hispaniola.

\section{Seasonal Abondance}

Our work on Diatraea saccharalis indicated no period of its maximum abundance general to all of Puerto Rico, yet every other caterpillar infesting sugar-cane: Laphygma, Mocis, the Hesperiids and even the rare $M$ rasmia, show the same seasonal reaction of greatest abundance in the late fall and early winter months. Why should Diatraea be the exception?

\section{YELLOW APHID}

Quite different from the Lepidoptera in its pattern of rection to season is the yellow aphid of sugar-cane, Sipha flava Forbes, which our observations indicate as having two periods of abundance. Most of the records are for the months of December, January and February, none in March, a few for April, and again abundance in May and June, with none for the summer and only a few for autumn. Regionally, it is a much more serious pest in the extreme eastern part of Puerto Rico, three-fourths of the records of serious infestations being from Guayama and Arroyo to Fajardo and Loíza. This can hardly be a reaction to the variety of cane grown, for $\mathrm{BH}$ (10) 12 is as much the standard cane for Guanica and Ponce as it is for Guayama and Loíza, while Fajardo with its own special seedlings suffers no less than Yabucoa and Arroyo.

During the period, but outside the region of our observations, especially heavy and prolonged infestations occurred during the autumn of 1940 around Caguas and Juncos, which were agravated by dry weather, and almost destroyed some fields of young gran cultura cane. Heavy rainfall in late October eliminated these infestations. The effect of the rain by continuously maintaiining a high humidity for several days, was to induce an epidemic of fungus disease caused by Acrostalagmus aphidum Oud. 
While epidemics of fungus disease are completely effective in control when, and only when suitable climatic conditions for their development occur, commercially effective control under any climatic conditions may, and often does result if the lady-beetle, Cycloneda sanguinea L., and others, and the Syrphid fly, Baccha latiuscula Loew, and others, are present in sufficient numbers. The value of these predators is considerably limited by their natural parasites, however, the natural balance thus resulting giving the aphids a chance to maintain their numbers, or at least to avoid total extermination locally. At other times, one may find large numbers of Cycloneda sanguinea adults wandering about in a rane field clearly showing indications of having been heavily infested by aphids not many days before, but now devoid of anything for the beetles to eat. Eventually they disperse widely by flight, but it was under such conditions that a larva, not able to get away thus easily, was noted attempting to extract nourishment from the empty egg-shells from which Diatraea caterpillars had hatched.

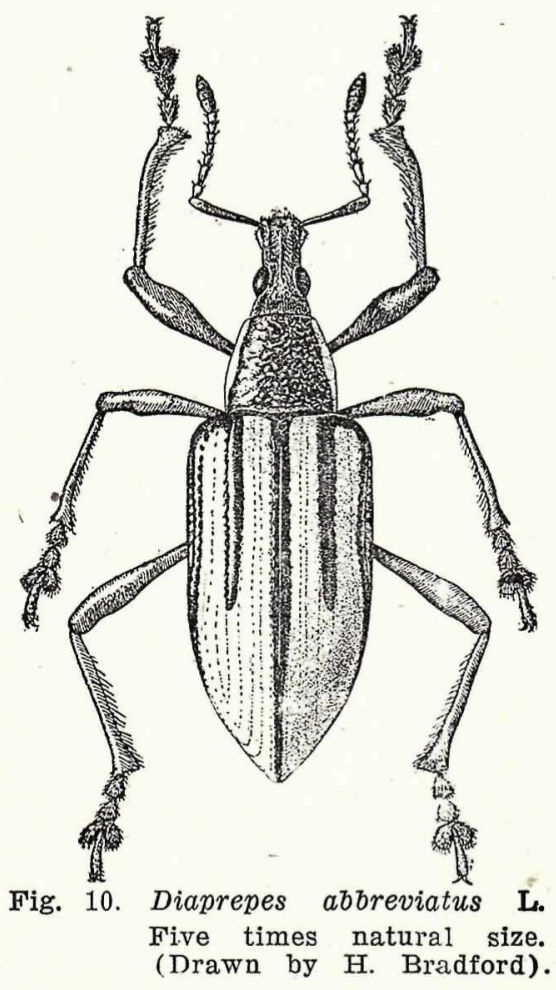


The presence of the brown aphid, Hysteroneura setariae Thomas, a very minor pest of sugar-cane, was noted once at Santa Isabel in November 1936, and not again recorded.

\section{VAQUITA}

The Otiorhynchid beetle commonly known in Puerto Rico as "vaquita", Diaprepes abbreviatus L. (Fig. 10), in its relations with sugarcane has been studied mostly as larvae burrowing into and feeding upon the root-stalk (Jones 1915). As so little is known about the eggs of the vaquita on sugar-cane in Puerto Rico, we made a definite effort to record

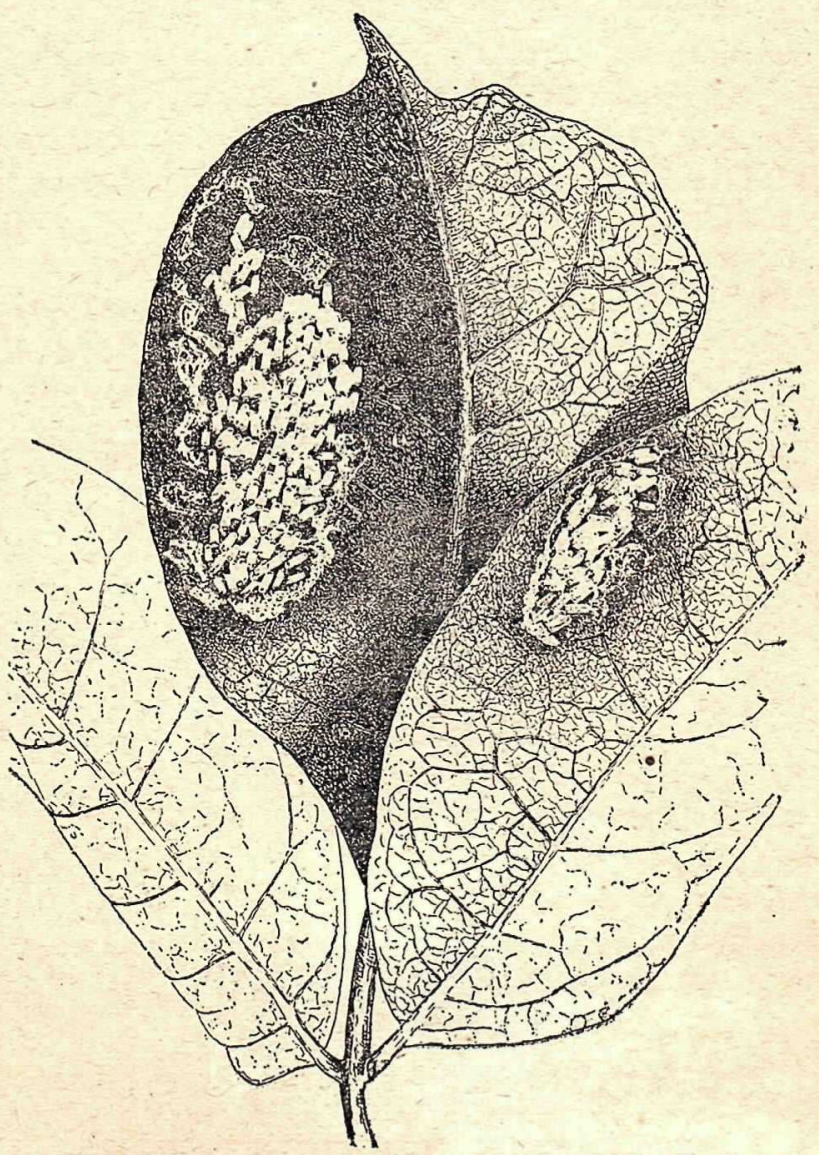

Fig. 11. Egg-clusters of Diaprepes abbreviatus $L$.. between leaves of jobo. Twice natural size. (Drawn by F. Seín). 
each collection. Our notes, however, represent only incidental collections, for the presence of the eggs is not obvious in most cases, and was usually detected by accident. Normally they are laid in masses of considerable size between the split ends of the leaves, altho we have several records of their being laid between two crossed or adjacent cane leaves, as is typical on the leaves of trees (Fig. 11). When laid on very tender cane leaves, their presence may result in the leaf turning reddish-brown clear thru to the other side, but instances of such distinctive pigmentation are rare. A few egg-clusters were noted on sugar-cane during the spring months, many in May, reaching a peak of greatest abundance in June. Some were found in July and August, with a secondary peak in abundance in September and October, decreasing greatly in abundance thereafter, so that none was found after early December. At Guanica, Guayanilla and Ponce, eggs were found only in the months of peak abundance of June and September, all the records for other months being at localities in the more humid parts of the Island.

One might suppose that abundance of eggrs parallels abundance of adults, but the adults feed by preference on so many other hosts that occurrence of eggs on cane does not necessarily imply parallel abundance of adults. One never finds hundreds and thousands of adults on cane, as is common on preferred individual host trees, but usually only an occasional individual, or rarely one or more pairs close together. While the grubs feed on the root-stalks of sugar-cane to such an extent as to be a major pest, adults rarely eat cane leaves, at least in Puerto Rico, greatly preferring the leaves of trees bordering cane fields. We have two definite records of Diaprepes adults eating tender cane leaves, however: at Isabela in March and at Naguabo in May, both recorded because such occurrences are so exceptional.

The specific parasite of Diaprepes eggs, Tetrastichus haitiensis Gahan, has the same peak of abundance in June, but normally attacks eggs laid between leaves that are less tough than the drying tips of those of sugarcane. Indeed, the failure of this parasite to survive in Barbados was thought by Mr. R. W. E. Tucker (1936) to be due to its inability to penetrate cane leaves, either for oviposition in the host eggs, or for emergence from them. Our notes record four instances of parasitism by Tetrastichus of vaquita eggs laid between cane leaves: two instances in May, at Luquillo and Rio Blanco, one in August at Isabela and another in December at Camuy. Quite possibly, however, these are such exceptional occurrences as to be immaterial in beneficially affecting the possibility 
of survival of the parasite in the hostile Barbadian environment. Indeed, they represent less than $5 \%$ of all egg-clusters collected, quite insignificant by comparison with almost total parasitism of Diaprepes egg-clusters laid between citrus or jagüey leaves in June.

\section{ThONALMUS}

The work of the economic entomologist so often deals with some foreign pest, accidentally introduced, that it is with the greatest pleasure that one can record the accidental introduction and establishment of an insect which not only is not a pest but a beautiful addition to the local fauna: Thonalmus dominicensis Bourgeois.

The Lesser Antilles to the east and south of $\mathrm{Puerto} \mathrm{Rico}$ are in general less rich in insect life than is Puerto Rico, and it is doubtful if many introductions, accidental or intentional, have come from this direction. Indeed, the only one of which we are at all certain, in recent times, is of the large Vespid wasp, Polistes major P. B., presumably blown in by the hurricane of 1928 (Bequaert 1936), and possibly one other, the pepper flower bud moth, Gnorimoschema gudmanella Walsingham, from the Virgin Islands. The much larger island of Hispaniola to the west, inhabited by many insects not found in Puerto Rico, is to the leeward both as to normal trade winds and hurricanes. Inter-island trafic, however, tends to bring numerous insects to Puerto Rico from Santo Domingo, not only in mahogany sawn lumber ("la bete d'argent", Polycesta porcata F., has emerged from furniture made in Puerto Rico of lumber imported from the Dominican Republic), but in unbarked railroad ties, and in cargoes of sugar-cane. To be sure, all the cane boats daily or triweekly bringing cane from La Romana to Ensenada during the grinding season are fumigated with sulfur, which actually has prevented the Hispaniolan cane butterfly, Calisto pulchella Lathy, from gaining entrance, or at least from becoming established in Puerto Rico.

When inspection of this fumigation was initiated by entomologists, it was common practice to wait until the boat was unloaded and see what dead insects could be collected in the empty hold. Among others was the bright red and blue Lycid beetle, Thonalmus chevrolati Bourgeois, first recorded by R. H. Van Zwaluwenburg from Puerto Rico and doubted by Leng \& Mutchler (1922). Nevertheless, Van Zwaluwenburg was right as to the presence of live beetles in Puerto Rico and of their establishment here, for whether they survived the sulfur fumigation, or arrived in Puerto Rico by some other means, the first records of their presence 
in cane fields are at Guanica (Wolcott \& Martorell 1937a). We first noted the live beetles in young cane near Yauco in March 193\%, at Guayanilla in June and September, and at Guanica in September and November. In 1938, beetles were noted only at Guanica, but in 1939 were abundant in March at Guanica, Guayanilla and Tallaboa, and again in midsummer and in the autumn at all of these points.

In March 1940, a single beetle was collected at Hda. Victoria, between Coloso and Aguadilla, and several were noted in the same or adjacent fields in April and July. The only records for 1941 are of collections in Ponce in May and June, possibly because records at former points of collection were no longer of primary interest. Unquestionably, all of the records at Guanica, Yauco, Guayanilla, Tallaboa and Ponce indieate a consistent dispersion along the south coast from the first introduction at Ensenada harbor, but this by no means accounts for the records at Coloso, an entirely different ecological region and one towards which no traffic occurs likely to carry the beetles from the south coast. The late Dr. Stuart T. Danforth records under the name Thonalmus dominicensis Chevrolat (Wolcott 1936), collection of this beetle at Hormigueros in August 1932 by Felipe Mora, to that extent at least filling in the gap between the pier at Ensenada and the cane fields of Coloso, and indicating dispersion up the west coast from the port of entry. A more intimate knowledge of the life-history of Thonalmus would be most desirable, for we can see no specific or necessary connection with sugar-cane. Of course, all of our records are from fields of sugar-cane, but with an equal amount of attention given to other environments, its relative abundance might prove to be much greater outside of cane fields, or its occurrence in them be due merely to the fact that they are humid, irrigated areas. Its dispersion to Coloso, against traffic in mature cane, all of which is goirg in the opposite direction towards Guanica Centrale, might indicate dispersion by flight, and possibly to a preferred environment in a more humid region, for the distance to Coloso is twice as great as to Ponce.

That we have not found this beetle on Mona Island, between Puerto Rico and Hispaniola, may be due to the xerophytic character of Mona, or it may be additional evidence of the probability of the introduction of Thonalmus into Puerto Rico by commerce, for there is little or none from Hispaniola to Mona Island.

\section{Twice - Stabbed Lady - Beetle}

Another recently introduced beetle, present also only by accident in cane fields, is the twice-stabbed lady-beetle, Chilocorus cacti L., noted 
twice near Manati in 1940 and in 1941. Presumably these are descended from adults released at Vega Baja and Barceloneta by the Mayaguez Station (Anon. 1939) as predators on the scales of bamboo. In the cane fields where noted, they were far from any scale-infested bamboo, but these lady-beetles feed on a great variety of scale insects on many different hosts. At Rio Piedras, they became very abundant on papaya and acalypha, feeding on the grey scale, Pseudoparlitoria ostreata Cockerell; on coconut feeding on Aspidiotus destructor Signoret, and on emajagua feeding on Pinnapis minor Maskell. At Isabela they have cleaned citrus trees of heavy infestations of Chionaspis citri Comstock; in the Maricao Insular Forest been observed feeding on scales on Trema lamarckiana; at Guanica feeding on Asterolecanium pustulans Cockerell on Colubrina colubrina, and most recently been recorded from Cabo Rojo feeding on Saissetia hemispherica Targioni on pigeon peas. It is hardly surprising, therefore, that these beetles wandering from hosts which they have cleaned of scales should now and then be found in cane fields, even if there is nothing in particular for them to eat there.

\section{OTHER INSECTS}

Several of the other insects noted in cane fields fill a specific niche in the environment where they were found, expressing a reaction to some particular factor in that environment. As a reaction to the burning of trash, numerous dead-hearts caused by the caterpillars of Elasmopalpus lignosellus Zeller were noted in a field near Toa Baja in June 193\%. During dry weather, one often sees a few chinch bugs, Blissus leucopterus Say, in the cane fields, the one record we have of considerable abundance being at Rio Grande in October 193\%. Cane planted on sandy land is often attacked by the changa, Scapteriscus vicinus Scudder (Fig. 12), such injury being so common that unless serious, we made no note of it. The records of worst injury are at Hda. San Isidoro near Patillas, at Santana near Arecibo, and Hda. Maria Teresa at Camuy. Another insect often noted in sandy land, but only indirectly connected with cane, is the Scoliid wasp, Campsomeris dorsata F., repeatedly noted in some sandy fields at Guanica in the winters of 1938 and 1939, and on red sandy land at Manatí. A large cluster of males was noted at Patillas in July before the middle of the afternoon, and many females frequenting the flowers of "verdolaga". Portulaca oleracea, at Guayanilla before 10 o'clock in the morning.

An abundance of, the large black Stratyomyid fly, Hermetia illucens 


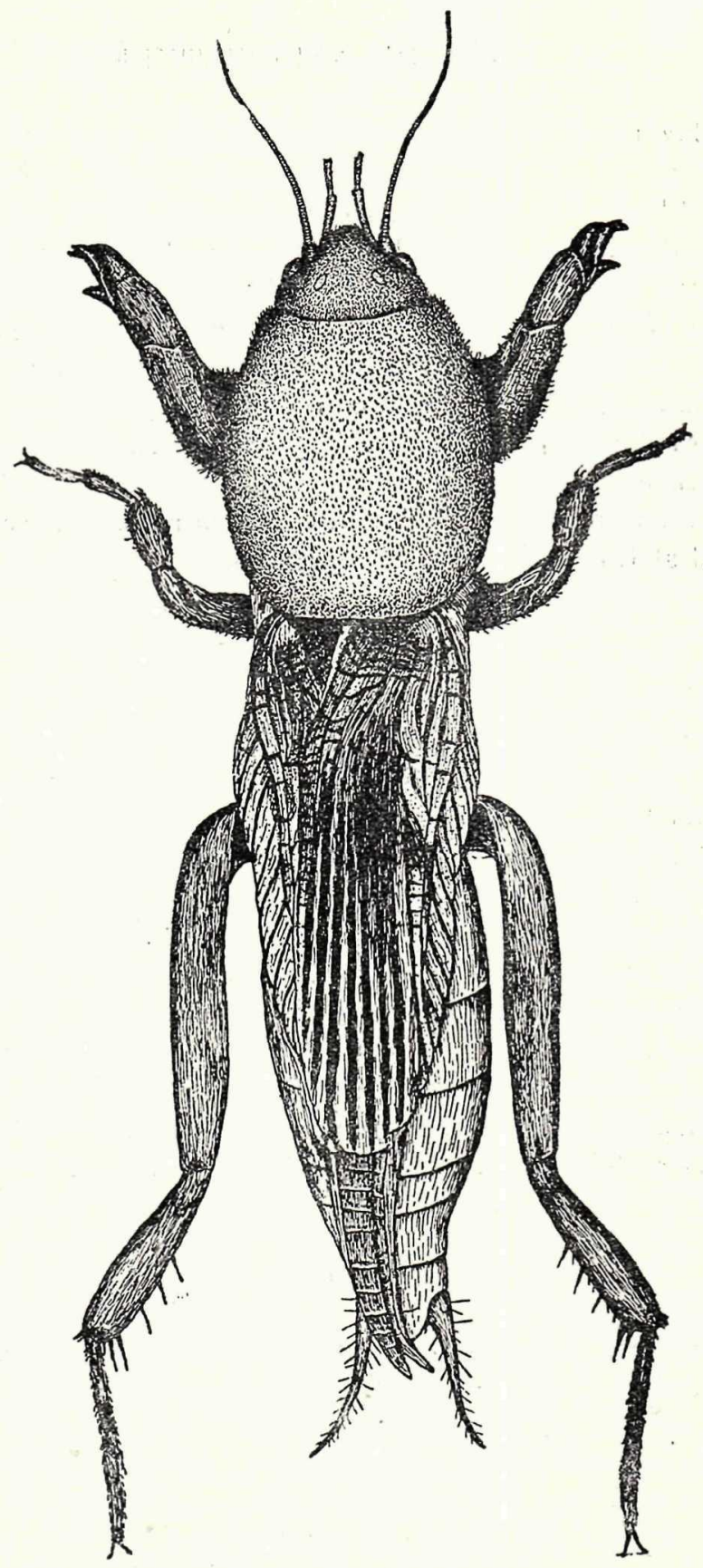

Fig. 12. The "Changa", of Puerto Rican MoleCricket, Scapteriscus vicinus Scudder, Six times natural size. (Drawn by F. Seín). 
L., presumably indicates heavy fertilization with organic manure or cachaza, or the presence near-by of a pile of such decaying organic material, on which the larvae are known to subsist. A few flies were often seen, but the only record of exceptional abundance is at Hda. Las Claras near Arecibo, in July 1939, just before noon. The presence of Euxesta thomae Loew in cane fields, was just a nuisance from our standpoint, because at first glance they often looked so much like parasitized or partly parasitized Diatraea egg-clusters, and in consequence they received not a single written record from us. Grallopoda (Calobata) lasciva F., another fly common in cane fields, was recorded only when numerous dead adults, stuck to the leaves by a white fungus, were noted at Canovanas in November 1936 and at Guayanilla in December 1938.

\section{Grasshoppers}

Cane grown in other countries adjacent to extensive uncultivated semi-desert regions often suffers severely from invasions of grasshoppers, but in Puerto Rico grasshoppers are rarely abundant in any environment, and have never been recorded as causing appreciable injury to cane. They do feed on the leaves of sugar-cane, nevertheless, and in a field of cane near Fajardo, now a housing development, little green Schistocerca nymphs were observed in November 1938, and at each succeeding observation were noted growing rapidly, had transformed to adults by February, which were still present in March when the cane became too high for further observations. A single large green grasshopper, Neoconocephalus triops L., was. observed feeding on a cane leaf at Camuy, and the wasp Tachytes insularis Cresson was noted carrying a smaller green grasshopper, Conocephalus cinereus Thunberg, to provision her nest, in a cane field at Toa Baja.

\section{A NEW Mrte}

Now that every cane grower, and nearly every laborer in the cane fields of Puerto Rico knows and recognizes mosaic disease, the simulation of this disease by the attack of multitudes of a little green mite living on the underside of cane leaves is becoming increasingly common. Mr. E. A. McGregor, a specialist in mites of the genus Tetranychus, has described it as new, with the type from Puerto Rico. Our notes fail to give all the records, but it was abundant in a field of M-28 near the new hospital at the top of the hill near Aguadilla, and noted on this variety 
of eane at several other points, as well as on standard varieties at Vega Baja in May 1940, at Quebradillas in July, and in great abundance in several fields near Arecibo in August 1941. The mites were first noted infesting sorghum growing in a greenhouse at Rio Piedras early in 1940. Possibly the heaviest infestation noted was at Loiza in August 1941 on $\mathrm{BH}$ (10) 12, where the mites were being attacked by small yellowish dipterous maggots, as well as by the larvae of very small black ladybeetles, identified by Dr. E. A. Chapin as a species of Stethorus. Actual injury by these mites has been negligible up to the present, but it is fortunate that checks on their abundance have already developed, and presumably will prevent this new pest from becoming more than a possible threat.

\section{SUMMARY}

Five years observations in fields of young cane in Puerto Rico indicate a marked seasonal abundance during autumn and early winter, of all caterpillars except those of Diatraea saccharalis F., the species noted being Laphygma frugiperda S. \& A., Mocis repanda F., Panoquina n. nero F., $P$. coscina Herrich-Schäffer, Perichares c. coridon F. and Marasmia trapezalis Guenée. The yellow aphid, Sipha flava Forbes, is most abundant during the winter and again in late spring, especially in eastern Puerto Rico. The eggs of Diaprepes abbreviatus L. are most abundant in June and September, and on the south coast were found only during these months. Thonalmus chevrolati Bourgeois, a red and blue Lycid beetle accidentally established at Guanica by introduction from "Santo Domingo, has spread north to Coloso and east to Ponce. The twice-stabbed lady-beetle, Chilocorus cacti L., introduced to prey upon the scales attacking bamboo, feeds on many other kinds of scales, and at times is found in cane fields. The injury produced by a new species of mite, Tetranychus sacchari McGregor, simulates mosaic disease.

\section{Literature Cited:}

Anon. 1939. Report of the Puerto Rico Experiment Station 1938. pp. 1-137. fig. 36. Washington, D. C., November 1939.

Bequaert, J. C., 1936. Two new Color Forms of Polistes major Palisot de Beauvois from California and Arizona. Entomological News, 47 (1) : 7-13. Philadelphia, January 1936.

Jones, Thos. H., 1913. Some Notes on Laphygma frugiperda S. \& A., in Porto Rico. Jour. Ec. Ent., 6 (2) : 230-6. Concord, N. H., April 1913. 
Jones, Thos. H., 1915. The Sugar Cane Weevil Root Borer (Diaprepes spengleri Linn.). Bul. No. 14, Insular Expt. Station, Río Piedras, pp. 19, fig. 11, San Juan, April 14, 1915.

Jones. Thos. H. \& Wolcott, G. N., 1922. The Caterpillars which eat the Leaves of Sugar-Cane in Porto Rico. Jour. Dept. Agr. P. R,. 6 (1) : 38-50, fig. 9. San Juan, October 1922.

Leng, C. W. d Itutchler, A. J., 1922. The Lycidae, Lampyridae and Cantharidae (Telephoridae) of the West Indies. Bul. Amer. Mus. Nat. Hist., 48 (8) : 413-499, fig. 65, New York, August 24, 1922.

Leonard, I. W., 1933. Notes on the Giant Toad. Bufo marinus (L.), in Puerto Rico. Jour. Ec. Ent., 26 (1) : 67-71, Geneva, N. Y, February 1933.

MeGregor. E. A., 1943 A New Spinning Mite attacking Sugar Cane in Puerto Rico. Jour. Agr. Univ. P. R., 26 (4): 91-94, pl. 1, Rfo Piedras, March 29, 1943.

Tncker. R. W. E. 1936. Parasites introduced into Barbados for the Control of Insect Pests. Agr. Jour. Barbados, 5 (1): 1-22, ref. 8. Bridgetown, January 1936.

Van Dine, D. L., 1913. The Insects affecting Sugar-Cane in Porto Rico, Jour. Ec. Ent. 6 (2) : 251- $\tau$, Concord, N. H., April 1913.

Wolcott, G. N., 1921. The Minor Sugar-Cane Insects of Puerto Rico. Jour. Dept. Agr. P. R., 5 (2) : 1-47. fig, 19. San Juan, April 1921.

Wolcott, G. N., 1929, Marasmia trapezalis Gueneé on Sugar-Cane only in Hispaniola and Peru in the Western Hemisphere. Jour, Ec. Ent. 22 (1): 268-9. Geneva, N. Y., February 1929.

Woleott. (x. N., 1935. The White Girub Problem in Puerto Rico. Fifth Congress, International Soc. Sugar-Cane Technologists, pp. 445-456, fig. 5, ref. 11. Brisbane, Queensland, September 1935.

Wolcott, G. N., 1936. "Insectae Borinquenses" a revised annatated ChrockList of the Insects of Puerto Rico, with a Host-Plant Index by José I. Otero. Jour. Agr. Univ. P. R., 20 (1): 1-627, illus, Río Piedras, July 10, 1936.

Wolcott, G. N. \& Hartorell, L.F., 1937. The Ant. Monomorium carbonarium ebeninum Forel, in a new Role: as Predator on the Egg-Clusters of Diatraea saccharalis $F$. in Puerto Rican Cane Fields. Jour. Agr. Univ. P. R., 21 (4): 577-80. San Juan, November 12, 1937.

Wolcott, G. N. \& Martorell, L. F., 193ia. Two Insects new to Puerto Rico: The Lycid Beetle, Tho:almus chevrolati Bourgeois, and the Ephydrid Fly, Ephydra yracilis Packard. Jour. Agr. Univ. P. R., 21 (4): 535-8. San Juan, November 12, 1937.

Actual Date of Publication : 